\title{
Multitarget drug design strategy in Alzheimer's disease: focus on cholinergic transmission and amyloid- $\beta$ aggregation
}

Elena Simoni", ${ }^{*}$, Manuela Bartolini' ${ }^{1}$, Izuddin F Abu ${ }^{2,6}$, Alix Blockley ${ }^{2}$, Cecilia Gotti ${ }^{4}$, Giovanni Bottegoni $^{3}$, Roberta Caporaso ${ }^{1}$, Christian Bergamini ${ }^{1}$, Vincenza Andrisano ${ }^{5}$, Andrea Cavalli $^{1,3}$, Ian R Mellor ${ }^{2}$, Anna Minarini ${ }^{1}$ \& Michela Rosini**,1

${ }^{1}$ Department of Pharmacy \& Biotechnology, Alma Mater Studiorum-University of Bologna, Via Belmeloro 6, 40126 Bologna, Italy

${ }^{2}$ School of Life Sciences, University of Nottingham, University Park, Nottingham, NG7 2RD, UK

${ }^{3}$ Drug Discovery \& Development, Istituto Italiano di Tecnologia, via Morego 30, 16163 Genova, Italy

${ }^{4} \mathrm{CNR}$, Institute of Neuroscience, Via Luigi Vanvitelli 32, 20129 Milano, Italy

${ }^{5}$ Department for Life Quality Studies, Alma Mater Studiorum-University of Bologna, Corso d'Augusto 237, 7921 Rimini, Italy

${ }^{6}$ Institute of Medical Science Technology, University of Kuala Lumpur, A1-1, Jalan TKS1, Taman Kajang Sentral, Selangor, 43000 Kajang, Malaysia

*Author for correspondence: Tel.: +39 051 2099706; elena.simoni@ unibo.it

**Author for correspondence: Tel.: +39 051 2099722; michela.rosini@unibo.it 


\begin{abstract}
Background: Alzheimer pathogenesis has been associated with a network of processes working simultaneously and synergistically. Over time, much interest has been focused on cholinergic transmission and its mutual interconnections with other active players of the disease. Besides the cholinesterase mainstay, the multifaceted interplay between nicotinic receptors and amyloid is actually considered to have a central role in neuroprotection. Thus, the multitarget drug-design strategy has emerged as a chance to face the disease network. Results: By exploiting the multitarget approach, the present study provides new molecules able to target the cholinergic pathway, by joining direct nicotinic receptor stimulation to acetylcholinesterase inhibition, and to inhibit $A \beta$ aggregation. Conclusions: These new compounds emerged as a suitable starting point for a further optimization process.
\end{abstract}

Keywords: Alzheimer's disease, Nicotinic receptors, Acetylcholinesterase inhibitors, Multitarget compounds, Amyloid aggregation. 


\section{Introduction}

Research into treatments for Alzheimer's disease (AD), the most common form of dementia that imparts a slow progression of cognitive decline, and ultimately death, has yet to yield to a substantial improvement in cure or prevention [1]. One of the major obstacles in developing effective drug therapies has been the lack of a single model that can adequately mimic all signs of the disease and, consequently, of a comprehensive hypothesis able to clarify the interconnected mechanisms behind the histopathological changes observed in $\mathrm{AD}$ patients. What is clear to date is that $\mathrm{AD}$ has a multifactorial nature, where multiple biological and genetic factors coexist [2]. In this complex scenario, two neurochemical defects have been almost universally described as occurring during the mild to moderate phase: cholinergic neuronal loss and beta-amyloid (A $\beta$ ) peptide misfolding and aggregation [3].

In the last decades, the cholinergic hypothesis has inspired the first-line treatment for AD. In particular, three of the four drugs currently approved by the US FDA (i.e. donepezil, rivastigmine, and galantamine) are directed towards temporary enhancing acetylcholine (ACh)-dependent neurotransmission through the inhibition of the enzyme acetylcholinesterase (AChE). ACh levels can also be restored in the short term by the inhibition of butyrylcholinesterase $(\mathrm{BChE})$, whose concentration gradually increases in advancing $\mathrm{AD}$, while AChE activity declines [4, 5]. Besides the cholinesterase (ChE) mainstay, much interest has also been directed to the modulation of neuronal nicotinic receptor (nAChR) activity [6]. In addition to their involvement in the cholinergic transmission, nAChRs are considered to play important roles in neuroprotection [7]. Several agonists of both $\alpha_{4} \beta_{2}$ and $\alpha_{7} \mathrm{nAChRs}$ have reached clinical evaluation in patients with mild to moderate $\mathrm{AD}$, demonstrating safety, tolerability, and positive effects across multiple cognitive domains [8]. There is in fact the consensus view that activation of nAChRs protects neurons from $\mathrm{A} \beta$ toxicity [9], and that $\mathrm{A} \beta$ and its oligomers target neurons at least partly via $\mathrm{nAChRs}$, sorting different effects ranging from synaptic potentiation to inhibition of neurotransmitter release, according to the peptide concentration [10]. In particular, physiological concentrations of A $\beta$ may directly stimulate $\alpha_{7} \mathrm{nAChRs}$, while at increasing $A \beta$ levels, in a pathological context, it impairs the cholinergic responses mediated by both $\alpha_{7}$ and $\alpha_{4} \beta_{2}$ receptors [3]. To corroborate the A $\beta$-nAChR correlation, some studies have also confirmed that activation of $\mathrm{nAChRs}$ contributes to decreased $\mathrm{A} \beta$ generation by modulating the amyloid precursor 
protein (APP) processing [3], protecting neurons from the peptide toxicity. Therefore, the amyloidogenic and cholinergic pathways, while being considered independent for years, share a number of molecular features that merge at several points. This intertwined correlation is part of a complex network of $A \beta$-centred pathogenic events that may possibly account for the failure hitherto encountered with purely anti-amyloid strategies.

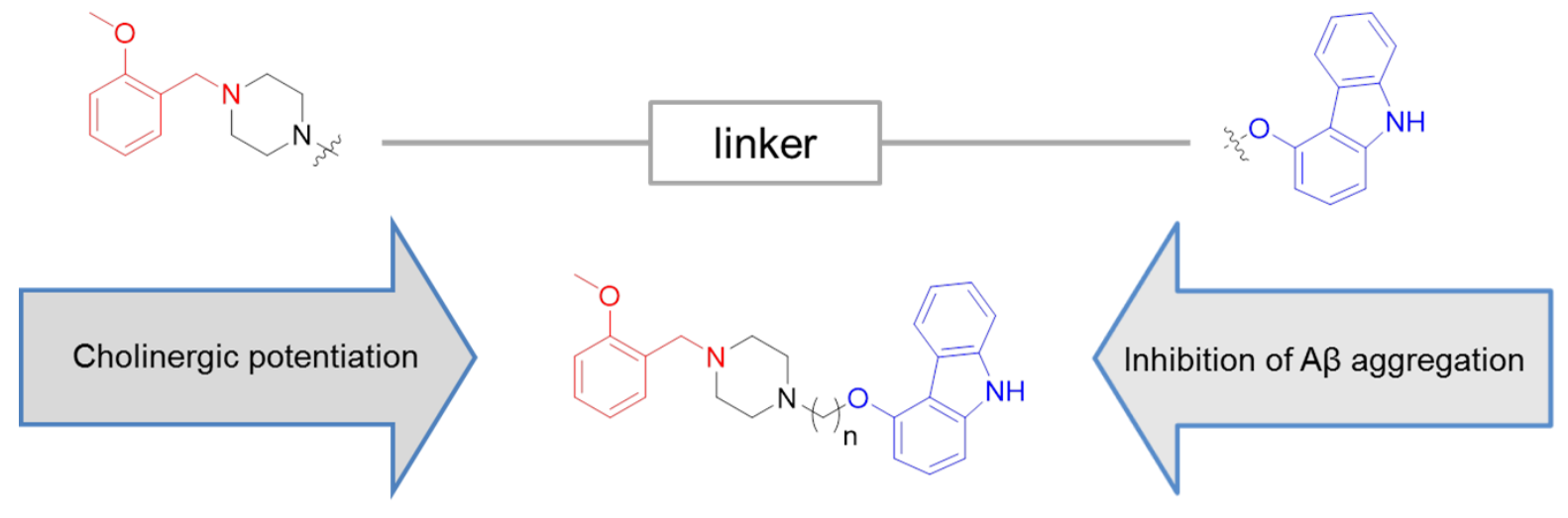

$1-5, n=3-7$

Figure 1. Rational Design of 1-5.

In this scenario, we envisaged the development of multitarget compounds, i.e. small molecules able to simultaneously address multiple targets critically involved in the AD network [11-13], as a promising therapeutic choice. In particular, we sought to exploit the abovementioned mutual interactions between $\mathrm{A} \beta$ and cholinergic transmission by endowing singular chemical entities of both antiaggregating ability and cholinergic properties (i.e. AChE inhibition and nAChR activation). To this end, we followed a ligand-based approach and combined synergistic pharmacophores into chimera compounds $\mathbf{1 - 5}$ by linking a 1-(2methoxybenzyl)-piperazine function to a carbazole moiety through different length spacers. Substituted carbazoles have shown to exert anti-amyloidogenic activity [14], and to interact with the AChE gorge (Figure 1)[15]. The selection of the 1-(2-methoxybenzyl)-piperazine function was based on the structural similarity between the ethyl-(2-methoxybenzyl)-amine group, that was already proven effective in 
recognizing the AChE catalytic site [16, 17], and the 1-(2,4-dimethoxyphenyl)-piperazine moiety, which demonstrated leading properties for $\alpha_{7} \mathrm{nAChR}$ activation [18].

\section{Materials \& methods}

Chemistry. Melting points were taken in glass capillary tubes on Buchi SMP-20 apparatus and are uncorrected. IR, electron impact (EI) mass, and direct infusion ESI-MS spectra were recorded on PerkinElmer 297, VG 7070E, and Waters ZQ 4000 apparatus, respectively. ${ }^{1} \mathrm{H}$ and ${ }^{13} \mathrm{C}$ NMR spectra were recorded on Varian VXR 200, 300 and 400 instruments. Chemical shifts are reported in parts per millions (ppm) relative to tetramethylsilane (TMS), and spin multiplicities are given as s (singlet), br s (broad singlet), d (doublet), $\mathrm{t}$ (triplet), or $\mathrm{m}$ (multiplet). Chromatographic separations were performed on silica gel columns by flash (Kieselgel 40, 0.040-0.063 mm; Merck) chromatography. Reactions were followed by thin-layer chromatography (TLC) on Merck (0.25 mm) glass-packed precoated silica gel plates (60 F254), then visualized in an iodine chamber or with an UV lamp.

Synthesis of 4-(7-Bromoeptyloxy)-9H-carbazole (11). It was synthesised according to Rosini et al.[15]: 1,7-dibromoheptane ( $8.19 \mathrm{mmol}, 3$ equiv) and catalytic amount of KI were added to a solution of 4hydroxycarbazole (6) (0.500 g, $2.73 \mathrm{mmol}, 1$ equiv) and powdered $\mathrm{KOH}(0.153 \mathrm{~g}, 2.73 \mathrm{mmol}, 1$ equiv) in $\mathrm{CH}_{3} \mathrm{CN}(25 \mathrm{~mL})$. After stirring at room temperature for $12 \mathrm{~h}$, the solvent was removed under vacuum, affording an oily residue that was purified by flash chromatography. Elution with $\mathrm{CH}_{2} \mathrm{Cl}_{2}$ /petroleum ether (3.5:6.5) afforded 11 as a white solid: $57 \%$ yield; $\mathrm{mp} 84-86{ }^{\circ} \mathrm{C} ;{ }^{1} \mathrm{H}$ NMR $\left(200 \mathrm{MHz}, \mathrm{CDCl}_{3}\right) \delta 1.37-2.16(\mathrm{~m}$, $10 \mathrm{H}), 3.37(\mathrm{t}, J=7.0 \mathrm{~Hz}, 2 \mathrm{H}), 4.41(\mathrm{t}, J=6.8 \mathrm{~Hz}, 2 \mathrm{H}), 6.72-6.76(\mathrm{~m}, 1 \mathrm{H}), 7.00-7.14(\mathrm{~m}, 1 \mathrm{H}), 7.29-7.53(\mathrm{~m}$, 4H), 8.10 (br s, $1 \mathrm{H}$ exchangeable with $\left.\mathrm{D}_{2} \mathrm{O}\right), 8.42(\mathrm{~d}, J=8 \mathrm{~Hz}, 1 \mathrm{H})$.

1-(2-Methoxy-benzyl)-piperazine (12). 1-Cloromethyl-2-methoxy-benzene ( $0.3 \mathrm{~mL}, 2.13 \mathrm{mmol}, 1 \mathrm{eq})$ was added dropwise to a solution of piperazine (1.85 g, $21.6 \mathrm{mmol}, 10 \mathrm{eq})$ and $\mathrm{K}_{2} \mathrm{CO}_{3}(0.55 \mathrm{~g}, 3.97 \mathrm{mmol}, 2 \mathrm{eq})$ in dry DMF $(15 \mathrm{~mL})$. The reaction mixture allowed to stir at rt. After $24 \mathrm{~h}$, the mixture was warmed up to 70 ${ }^{\circ} \mathrm{C}$ for $4 \mathrm{~h}$ and the solvent was then evaporated. A solution of $\mathrm{KHSO}_{4}$ was added to the crude product and extracted with $\mathrm{CH}_{2} \mathrm{Cl}_{2}$. The acidic solution was made basic with $\mathrm{KOH}$ and extracted again with $\mathrm{CH}_{2} \mathrm{Cl}_{2}$; the combined extract layers were dried and evaporated to give 12: 95\% yield; ${ }^{1} \mathrm{H} \mathrm{NMR}\left(300 \mathrm{MHz}, \mathrm{CDCl}_{3}\right) \delta$ 
2.27-2.37 (m, 4H), 2.65-2.70 (m, 4H), $3.37(\mathrm{~s}, 2 \mathrm{H}), 3.60(\mathrm{~s}, 3 \mathrm{H}), 6.66(\mathrm{~d}, J=7.8 \mathrm{~Hz}, 1 \mathrm{H}), 6.74(\mathrm{t}, J=7.5 \mathrm{~Hz}$, $1 \mathrm{H}), 7.03(\mathrm{t}, J=7.5 \mathrm{~Hz}, 1 \mathrm{H}), 7.19(\mathrm{~d}, J=7.8 \mathrm{~Hz}, 1 \mathrm{H}), 7.79$ (br s, $1 \mathrm{H}$ exchangeable with $\left.\mathrm{D}_{2} \mathrm{O}\right)$.

General procedure for the synthesis of 1-5. The appropriate bromide (1.02 mmol, 1 equiv) and a catalytic amount of KI were added to a solution of $12\left(0.21 \mathrm{~g}, 1.02 \mathrm{mmol}, 1\right.$ equiv) and powdered $\mathrm{K}_{2} \mathrm{CO}_{3}(0.14 \mathrm{~g}, 1.02$ mmol, 1 equiv) in dry DMF ( $5 \mathrm{~mL})$. After stirring under $\mathrm{N}_{2}$ atmosphere for $6 \mathrm{~h}$ at $70{ }^{\circ} \mathrm{C}$, the solvent was removed under vacuum, affording a residue that was purified by flash chromatography.

4-\{3-[4-(2-Methoxy-benzyl)-piperazin-1-yl]-propoxy\}-9H-carbazole (1). It was synthesized from 7 [15] $(0.31 \mathrm{~g}, 1.02 \mathrm{mmol})$ and purified by flash chromatography. Elution with a gradient system petroleum ether/ethyl acetate/EtOH (from 6.1:3.8:0.7 to 6.4:3.8:0.7 to 6.6:3.8:0.7 ) afforded 1 as a solid: 54\%yield; mp 97-99 ${ }^{\circ} \mathrm{C} ;{ }^{1} \mathrm{H}$ NMR $\left(400 \mathrm{MHz}, \mathrm{CDCl}_{3}\right) \delta$ 1.37-1.39 (m, 2H), 2.13-2.17 (m, 2H), 2.63-2.71 (m, 8H), $3.65(\mathrm{~s}$, 2H), $3.77(\mathrm{~s}, 3 \mathrm{H}), 4.22(\mathrm{t}, J=6.6 \mathrm{~Hz}, 2 \mathrm{H}), 6.61(\mathrm{~d}, J=8.2 \mathrm{~Hz}, 1 \mathrm{H}), 6.84(\mathrm{~d}, J=8 \mathrm{~Hz}, 1 \mathrm{H}), 6.90-6.94(\mathrm{~m}$, $1 \mathrm{H}), 6.98(\mathrm{~d}, J=8.2 \mathrm{~Hz}, 1 \mathrm{H}), 7.17-7.33(\mathrm{~m}, 6 \mathrm{H}), 8.25(\mathrm{~d}, J=8 \mathrm{~Hz}, 1 \mathrm{H}), 8.39$ (br s, $1 \mathrm{H}$ exchangeable with $\left.\mathrm{D}_{2} \mathrm{O}\right) .{ }^{13} \mathrm{C} \mathrm{NMR}\left(100 \mathrm{MHz}, \mathrm{CDCl}_{3}\right) \delta 26.83,52.62(2 \mathrm{C}), 52.95,55.37,55.46(2 \mathrm{C}), 55.83,66.14,100.91$, $103.46,109.97,110.49,112.54,119.49,120.34,122.61,122.91(2 \mathrm{C}), 124.82,126.58,128.45,131.01$, 138.71, 140.94, 155.46, 157.89. MS (ESI $\left.{ }^{+}\right): m / z 430[\mathrm{M}+\mathrm{H}]^{+}$.

4-\{4-[4-(2-Methoxy-benzyl)-piperazin-1-yl]-butoxy\}-9H-carbazole (2). It was synthesized from 8 [15] $(0.32 \mathrm{~g}, 1.02 \mathrm{mmol})$ and purified by flash chromatography. Elution with a gradient system from petroleum ether/ethyl acetate/EtOH (5.5:4.0:0.05) to petroleum ether/ethyl acetate/EtOH/ ammonia solution $30 \%$ (from 6.1:3.8:0.1:0 to 6.1:3.8:0.1:0.001), afforded 2 as a solid: yield $46 \% ;{ }^{1} \mathrm{H}$ NMR $\left(200 \mathrm{MHz}, \mathrm{CDCl}_{3}\right) \delta 1.18-1.39$ $(\mathrm{m}, 2 \mathrm{H}), 1.82-1.86(\mathrm{~m}, 2 \mathrm{H}), 1.95-2.05(\mathrm{~m}, 2 \mathrm{H}), 2.47-2.61(\mathrm{~m}, 8 \mathrm{H}), 3.65(\mathrm{~s}, 2 \mathrm{H}), 3.79(\mathrm{~s}, 3 \mathrm{H}), 4.24(\mathrm{t}, J=6.2$ $\mathrm{Hz}, 2 \mathrm{H}), 6.66(\mathrm{~d}, J=7.8 \mathrm{~Hz}, 1 \mathrm{H}), 6.85-7.02(\mathrm{~m}, 3 \mathrm{H}), 7.24-7.38(\mathrm{~m}, 6 \mathrm{H}), 8.33(\mathrm{~d}, J=7.8 \mathrm{~Hz}, 1 \mathrm{H}), 8.56(\mathrm{br} \mathrm{s}$, $1 \mathrm{H}$ exchangeable with $\left.\mathrm{D}_{2} \mathrm{O}\right) .{ }^{13} \mathrm{C}$ NMR $\left(100 \mathrm{MHz}, \mathrm{CDCl}_{3}\right) \delta 25.65,27.30,51.42(2 \mathrm{C}), 52.36,54.24,54.96$ (2C), 55.03, 66.00, 101.03, 102.94, 108.87, 109.69, 111.34, 118.65, 119.34, 121.31, 122.36, 122.81, 124.17, 126.03, 127.05, 130.91, 137.76, 141.24, 154.62, 157.79. MS $\left(\mathrm{ESI}^{+}\right): \mathrm{m} / z 444[\mathrm{M}+\mathrm{H}]^{+}$.

4-\{5-[4-(2-Methoxy-benzyl)-piperazin-1-yl]-pentyloxy\}-9H-carbazole (3). It was synthesized from 9 [15] $(0.34 \mathrm{~g}, 1.02 \mathrm{mmol})$ and purified by flash chromatography. Elution with petroleum ether/ $\mathrm{CH}_{2} \mathrm{Cl}_{2} / \mathrm{EtOH} /$ 
ammonia solution 30\% (7:2.5:0.5:0.025) afforded 3 as a solid: yield 57\% ; mp 110-112 ${ }^{\circ} \mathrm{C} ;{ }^{1} \mathrm{H}$ NMR (200 $\left.\mathrm{MHz}, \mathrm{CDCl}_{3}\right) \delta 1.61-1.64(\mathrm{~m}, 4 \mathrm{H}), 1.96-1.99(\mathrm{~m}, 2 \mathrm{H}), 2.37-2.40(\mathrm{~m}, 2 \mathrm{H}), 2.57-2.66(\mathrm{~m}, 8 \mathrm{H}), 3.67(\mathrm{~s}, 2 \mathrm{H})$, $3.75(\mathrm{~s}, 3 \mathrm{H}), 4.21(\mathrm{t}, J=6.2 \mathrm{~Hz}, 2 \mathrm{H}), 6.65(\mathrm{~d}, J=7.4 \mathrm{~Hz}, 1 \mathrm{H}), 6.88-7.02(\mathrm{~m}, 3 \mathrm{H}), 7.24-7.40(\mathrm{~m}, 6 \mathrm{H}), 8.36(\mathrm{~d}$, $J=7.4 \mathrm{~Hz}, 1 \mathrm{H}), 8.92\left(\right.$ br s, $1 \mathrm{H}$ exchangeable with $\left.\mathrm{D}_{2} \mathrm{O}\right) .{ }^{13} \mathrm{C} \mathrm{NMR}\left(100 \mathrm{MHz}, \mathrm{CDCl}_{3}\right) \delta 23.62,25.36,28.78$, $52.36(2 \mathrm{C}), 53.98,54.85,55.16(2 \mathrm{C}), 55.63,67.22,101.00,103.23,107.32,109.87,112.63,119.54,122.75$, $122.94(2 \mathrm{C}), 123.56,124.82,125.69,126.63,129.58,138.63,140.87,155.64,156.79 . \mathrm{MS}\left(\mathrm{ESI}^{+}\right): \mathrm{m} / z 458$ $[\mathrm{M}+\mathrm{H}]^{+}$.

4-\{6-[4-(2-Methoxy-benzyl)-piperazin-1-yl]-hexyloxy\}-9H-carbazole (4). It was synthesized from 10 [15] ( $0.35 \mathrm{~g}, 1.02 \mathrm{mmol})$ and purified by flash chromatography. Elution with: $\mathrm{CH}_{2} \mathrm{Cl}_{2} /$ petroleum ether/EtOH/ammonia solution 30\% (4:5.5:0.5:0.02) afforded 4 as a solid: yield $71 \% ; \operatorname{mp} 118-121{ }^{\circ} \mathrm{C} ;{ }^{1} \mathrm{H}$ NMR (400 MHz, DMSO- $\left.d_{6}\right) \delta$ 1.37-1.44 (m, 4H), 1.54-1.57 (m, 2H), 1.86-1.90 (m, 2H), 2.23-2.26 (m, 2H), 2.57-2.67 (m, 8H), $3.33(\mathrm{~s}, 2 \mathrm{H}), 3.74(\mathrm{~s}, 3 \mathrm{H}), 4.16(\mathrm{t}, J=6.2 \mathrm{~Hz}, 2 \mathrm{H}), 6.65(\mathrm{~d}, J=8 \mathrm{~Hz}, 1 \mathrm{H}), 6.89-6.95(\mathrm{~m}$, 2H), 7.04 (d, $J=8 \mathrm{~Hz}, 1 \mathrm{H}), 7.11-7.14,(\mathrm{~m}, 1 \mathrm{H}), 7.16-7.19(\mathrm{~m}, 1 \mathrm{H}), 7.25-7.33(\mathrm{~m}, 3 \mathrm{H}), 7.42-7.44(\mathrm{~m}, 1 \mathrm{H})$, $8.12(\mathrm{~d}, J=8 \mathrm{~Hz}, 1 \mathrm{H}), 11.06$ (br s, $1 \mathrm{H}$ exchangeable with $\left.\mathrm{D}_{2} \mathrm{O}\right) .{ }^{13} \mathrm{C}$ NMR $\left(100 \mathrm{MHz}\right.$, DMSO- $\left.d_{6}\right) \delta 25.47$, $26.10,26.47,28.68,52.62,52.73,55.10(2 \mathrm{C}), 55.21,57.63(2 \mathrm{C}), 67.10,100.21,103.51,110.22,110.54$, $111.28,118.37,119.86,121.59,121.91,124.29,125.63,126.32,127.69,129.50,138,72,140.91,124.84$, 157.13. MS (ESI $\left.{ }^{+}\right): m / z 472[\mathrm{M}+\mathrm{H}]^{+}$.

4-\{7-[4-(2-Methoxy-benzyl)-piperazin-1-yl]-eptyloxy\}-9H-carbazole (5). It was synthesized from $11(0.37$ $\mathrm{g}, 1.02 \mathrm{mmol}$ ) and purified by flash chromatography. Elution with petroleum ether/ethyl acetate/EtOH (7.16:2.5:0.34) afforded 5 as a solid: yield $52 \% ;{ }^{1} \mathrm{H}$ NMR $\left(400 \mathrm{MHz}, \mathrm{CDCl}_{3}\right) \delta 1.28-1.56(\mathrm{~m}, 10 \mathrm{H}), 1.93(\mathrm{t}, J$ $=6.4 \mathrm{~Hz}, 2 \mathrm{H}), 2.31(\mathrm{t}, J=7.4 \mathrm{~Hz}, 2 \mathrm{H}), 2.51-2.61(\mathrm{~m}, 6 \mathrm{H}), 3.62(\mathrm{~s}, 2 \mathrm{H}), 3.72(\mathrm{~s}, 3 \mathrm{H}), 4.17(\mathrm{t}, J=6.4 \mathrm{~Hz}$, $2 \mathrm{H}), 6.61(\mathrm{~d}, J=8 \mathrm{~Hz}, 1 \mathrm{H}), 6.82(\mathrm{~d}, J=8 \mathrm{~Hz}, 1 \mathrm{H}), 6.92-6.94(\mathrm{~m}, 2 \mathrm{H}), 7.22-7.34(\mathrm{~m}, 6 \mathrm{H}), 8.31(\mathrm{~d}, J=8 \mathrm{~Hz}$, 1H), 8.89 (br s, $1 \mathrm{H}$ exchangeable with $\left.\mathrm{D}_{2} \mathrm{O}\right) .{ }^{13} \mathrm{C} \mathrm{NMR}\left(100 \mathrm{MHz}, \mathrm{CDCl}_{3}\right) \delta 26.13,26.44,27.47,29.23$, 29.36, 52.64 (2C), 52.88, 55.30 (2C), 56.10, 58.53, 67.80, 100.76, 103.40, 110.02, 110.50, 112.54, 119.29,

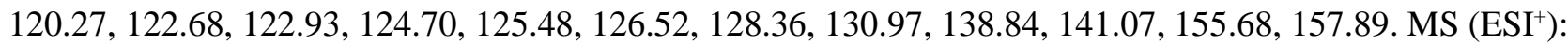
$m / z 486[\mathrm{M}+\mathrm{H}]^{+}$. 


\section{Biology}

Inhibition of AChE and BChE. The capacity of compounds 1-5 to inhibit human AChE and BChE activity was assessed using the Ellman's assay [19]. A Jasco V-530 double beam spectrophotometer connected to HAAKE DC30 thermostating system (Thermo Haake, Germany) was used. Stock solutions of the tested compound (1 or $2 \mathrm{mM}$ ) were prepared in methanol and diluted in methanol. The assay solution consisted of a 0.1 M phosphate buffer, $\mathrm{pH} 8.0$, with the addition of $340 \mu \mathrm{M}$ 5,5'-dithiobis(2-nitrobenzoic acid), 0.02 unit/mL human recombinant $\mathrm{AChE}$ or BChE from human serum (Sigma-Aldrich, Italy), and $550 \mu \mathrm{M}$ substrate, i.e., acetylthiocholine iodide (ACTh) or butyrylthiocholine iodide (BTCh), respectively (SigmaAldrich, Italy). Test compounds were added to the assay solution at increasing concentrations and preincubated at $37^{\circ} \mathrm{C}$ with the enzyme for $20 \mathrm{~min}$ before the addition of substrate. The rate of absorbance increase at $412 \mathrm{~nm}$ was followed for $5 \mathrm{~min}$. In parallel, blanks containing all components except the enzyme were prepared to account for the non enzymatic hydrolysis of the substrate. The reaction rates were compared and the percent inhibition due to the presence of test compounds was calculated. Each concentration was analyzed in duplicate/triplicate. The percent inhibition of the enzyme activity due to the presence of increasing concentrations of the compound was calculated. Inhibition plots were obtained for each compound by plotting the \% inhibition versus the logarithm of inhibitor concentration in the assay solution. The linear regression parameters were determined for each curve and the $\mathrm{IC}_{50}$ extrapolated.

Determination of the inhibitory effect on the $A \beta(1-42)$ self-aggregation [20]. To investigate the $A \beta(1-42)$ self-aggregation, a thioflavin T (ThT)-based fluorometric assay was performed. 1,1,1,3,3,3,-hexafluoro-2propanol-pretreated $\mathrm{A} \beta(1-42)$ samples (Bachem $\mathrm{AG}$, Germany) were resolubilized with a $\mathrm{CH}_{3} \mathrm{CN} / 0.3 \mathrm{mM}$ $\mathrm{Na}_{2} \mathrm{CO}_{3} / 250 \mathrm{mM} \mathrm{NaOH}(48.4: 48.4: 3.2)$ to have a stable stock solution $([\mathrm{A} \beta]=500 \mu \mathrm{M})$. Experiments were performed by incubating the peptide in $10 \mathrm{mM}$ phosphate buffer $(\mathrm{pH} 8.0)$ containing $10 \mathrm{mM} \mathrm{NaCl}$ at $30{ }^{\circ} \mathrm{C}$ for $24 \mathrm{~h}$ (final $\mathrm{A} \beta=$ concentration $50 \mu \mathrm{M}$ ) with and without the tested compound at $10 \mu \mathrm{M}$. To quantify amyloid fibril formation, the thioflavin T fluorescence method was used [21, 22]. After incubation, the samples were diluted to a final volume of $2.0 \mathrm{~mL}$ with $50 \mathrm{mM}$ glycine- $\mathrm{NaOH}$ buffer $(\mathrm{pH} 8.5)$ containing 1.5 $\mu \mathrm{M}$ ThT. A $300 \mathrm{~s}$ time scan of fluorescence intensity was carried out $(\lambda \mathrm{exc}=446 \mathrm{~nm}, \lambda \mathrm{em}=490 \mathrm{~nm})$, and 
values at the plateau were averaged after subtraction of the background fluorescence of the $1.5 \mu \mathrm{M}$ ThT solution.

Binding to nicotinic receptor subtypes. Frozen cortex and hippocampus specimens taken from adult male Sprague-Dawley rats (Charles River, Calco Italy) were homogenised using a Potter homogenizer in an excess of buffer A (50 mM Tris-HCl, $\mathrm{pH} 7,120 \mathrm{mM} \mathrm{NaCl}, 5 \mathrm{mM} \mathrm{KCl}, 1 \mathrm{mM} \mathrm{MgCl}_{2}$ and $2.5 \mathrm{mM} \mathrm{CaCl}_{2}$ and $2 \mathrm{mM}$ phenylmethylsulfonyl fluoride), centrifuged (60 min at 30,000 $\mathrm{xg}$ ), and rinsed twice. The homogenates were resuspended in the same buffer containing $20 \mu \mathrm{g} / \mathrm{ml}$ of the protease inhibitors leupeptin, bestatin, pepstatin $\mathrm{A}$, and aprotinin.

$\left[{ }^{3} \mathrm{H}\right]$-Epibatidine and $\left[{ }^{125} \mathrm{I}\right]$ - $\alpha$-bungarotoxin binding to $\alpha_{4} \beta_{2}$ cortical and $\alpha_{7}$ hippocampal membrane-subtypes were per formed as previously described [23]. For $\left[{ }^{125} \mathrm{I}\right]-\alpha$-bungarotoxin, non-specific binding was determined in parallel by means of incubation in the presence of $1 \mu \mathrm{M}$ unlabelled $\alpha$-bungarotoxin and for $\left[{ }^{3} \mathrm{H}\right]$-epibatidine, non-specific binding was determined by incubation with $10 \mathrm{nM}$ epibatidine The inhibition of $\left[{ }^{3} \mathrm{H}\right]$-epibatidine and $\left[{ }^{125} \mathrm{I}\right]$ - $\alpha$-bungarotoxin binding by nicotine the compounds was measured by incubating samples with increasing concentrations of each compound for five minutes followed by overnight incubation, at $4{ }^{\circ} \mathrm{C}$, with $0.1 \mathrm{nM}\left[{ }^{3} \mathrm{H}\right]$-epibatidine (in the case of the $\alpha_{4} \beta_{2} \mathrm{nAChR}$ and at room temperature with $2 \mathrm{nM}\left[{ }^{125} \mathrm{I}\right]-\alpha$-bungarotoxin for the $\alpha_{7} \mathrm{nAChR}$ subtype. After incubation, the membrane-bound $\alpha_{4} \beta_{2}$ and $\alpha_{7} \mathrm{nAChR}$ subtypes were washed five times with ice-cold PBS. $\left[{ }^{3} \mathrm{H}\right]$-Epibatidine binding was determined by means of liquid scintillation counting in a $\beta$ counter, and $\left[{ }^{125} \mathrm{I}\right]-\alpha$-bungarotoxin samples by direct counting in a $\gamma$ counter.

The LIGAND program was used to calculate $K_{\mathrm{i}}$ values of all the tested compounds using data obtained from at least three independent saturation and competition binding experiments.

Agonism of nAChRs. To test for agonism of $\alpha_{4} \beta_{2}$ or $\alpha_{7}$ receptors, cRNAs encoding the receptor subunits were injected into defolliculated Xenopus oocytes. $50 \mathrm{~nL}$ of cRNA solution containing $100 \mathrm{ng} / \mu \mathrm{L}$ each of $\alpha_{4}$ and $\beta_{2}$ or $\alpha_{7}$ was injected into each oocyte and they were incubated for three days at $18{ }^{\circ} \mathrm{C}$ for protein expression to take place. The oocytes were then subjected to two-electrode voltage clamp using an 
Axoclamp 2B (Axon Instruments, USA). Glass microelectrodes had a resistance of 0.5-1 M $\Omega$ when filled with $3 \mathrm{M} \mathrm{KCl}$. The oocytes were clamped at $-80 \mathrm{mV}$ then $\mathrm{ACh}$ and compounds $\mathbf{1 - 5}$ were applied to the oocyte using an 8-channel perfusion system (Automate, USA). Currents were transferred to a PC and measured using Strathclyde Electrophysiology Software WinEDRv3.6.9. (Dr John Dempster, University of Strathclyde, UK). Currents in response to 1-5 were normalized to the response to ACh at the same concentration and in the same cell and plotted as \% of ACh response \pm SEM using Graphpad Prism 7.01.

\section{Computational Methods}

The docking simulations were performed using ICM 3.8 (Molsoft LLC, San Diego - CA, USA). The enzyme model was prepared starting from the crystallographic coordinates of the complex formed by human AChE with fasciculin (PDBid: 1B41) [24] according to procedure reported in Belluti et al.[25]. Hydrogen atoms were added. Polar hydrogen atoms and the positions of asparagine and glutamine side chain amidic groups were optimized and assigned the lowest energy conformation. After optimization, histidines were assigned the tautomerization state which improved the hydrogen bonding pattern. Fasciculin was deleted and only the enzyme chain was retained. Ligands were built defining the right bond orders, stereochemistry, hydrogen atoms, and protonation states. Each ligand was assigned the MMFF force field atom types and charges [26]. The residues defining the binding pocket were selected according to the crystallographic poses of propidium in complex with the murine AChE (PDB code 1N5R) [27] and Donepezil (in complex with T. californica AChE, PDB code 1EVE) [28]. Sampling was performed using the Biased Probability Monte Carlo (BPMC) stochastic optimizer in an internal coordinate space as implemented in ICM [29]. Pre-calculated potential grid maps, representing Van der Waals potentials for hydrogens and heavier atoms, electrostatics, hydrophobicity, and hydrogen bonding, described the binding site. The adopted force field was a modified version of ECEPP/3 [30]. Based on the number of rotatable bonds in the ligand, the total number of BPMC steps to be carried out was calculated by an adaptive algorithm (thoroughness 1.0). The binding energy was assessed by means of the standard ICM empirical scoring function [31]. 


\section{Results \& discussion}

Compounds 1-5 were prepared following the synthetic procedures outlined in Figure 2. Nucleophilic substitution of the commercially available $\mathbf{6}$ with the opportune dibromo alkane gave intermediates 7-11 according to the procedure reported in Rosini et al.[15]. 1-(2-methoxybenzyl)-piperazine (12), synthesized treating 1-cloromethyl-2-methoxybenzene with a large excess of piperazine, was then condensed with intermediates 7-11 under basic conditions to afford final compounds 1-5.

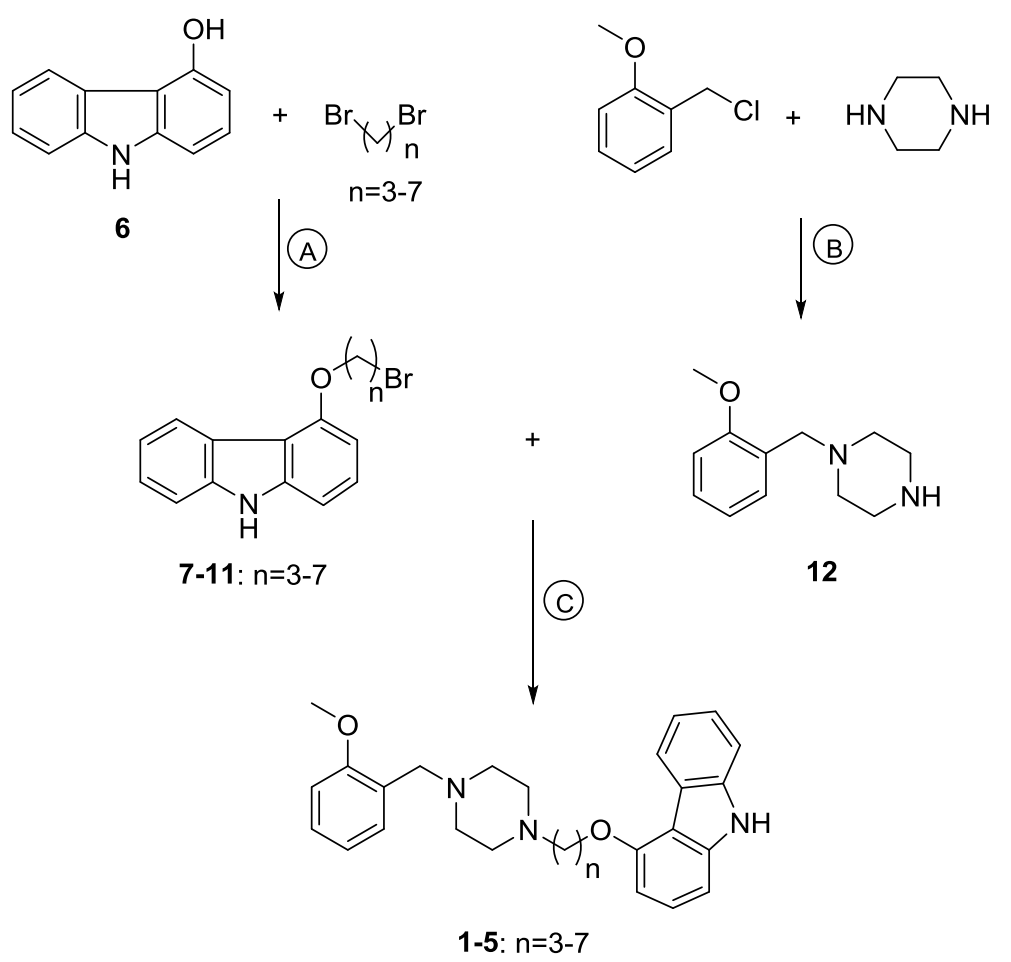

Figure 2. Synthesis of 1-5. Reagents and conditions: (A) $\mathrm{KOH}, \mathrm{CH}_{3} \mathrm{CN}$; rt; (B) $\mathrm{K}_{2} \mathrm{CO}_{3}$, DMF; (C) $\mathrm{K}_{2} \mathrm{CO}_{3}$, DMF, $\mathrm{N}_{2}$, reflux.

Initially, to determine the potential interest of compounds $\mathbf{1 - 5}$ as multifunctional agents for $\mathrm{AD}$ treatment, their AChE inhibitory activity was evaluated on human recombinant AChE by the method of Ellman and coworkers [19]. The inhibitory activity towards BChE from human serum of $\mathbf{1 - 5}$ was also determined by the same assay. 
Table 1 Inhibitory activity of human AChE and BChE, and amyloid aggregation by 1-5 and reference compounds.

\begin{tabular}{|c|c|c|c|c|}
\hline Compd & $\mathrm{n}$ & $\begin{array}{l}\text { hAChE inhibition } \\
\mathrm{IC}_{50}(\mathrm{M}) \pm \mathrm{SEM}^{\mathrm{a}}\end{array}$ & $\begin{array}{l}\text { hBChE inhibition } \\
\mathrm{IC}_{50}(\mathrm{M}) \pm \mathrm{SEM}^{\mathrm{a}}\end{array}$ & $\begin{array}{l}\% \text { inhibition } \\
\text { of } A \beta \\
\text { self-induced } \\
\text { aggregation } \pm \\
\text { SEM }^{\text {a b }}\end{array}$ \\
\hline 1 & 3 & $(2.12 \pm 0.47) 10^{-4}$ & $(5.10 \pm 0.38) 10^{-7}$ & $18.3 \pm 0.8$ \\
\hline 2 & 4 & $(3.19 \pm 0.32) 10^{-5}$ & $(7.56 \pm 0.19) 10^{-7}$ & $33.4 \pm 0.1$ \\
\hline 3 & 5 & $(2.39 \pm 0.06) 10^{-6}$ & $(6.32 \pm 0.31) 10^{-7}$ & $33.6 \pm 0.1$ \\
\hline 4 & 6 & $(7.73 \pm 0.40) 10^{-7}$ & $(1.84 \pm 0.06) 10^{-6}$ & $28.3 \pm 1.1$ \\
\hline 5 & 7 & $(5.01 \pm 0.35) 10^{-4}$ & $(5.71 \pm 0.22) 10^{-7}$ & $32.0 \pm 2.0$ \\
\hline 6 & - & nd & nd & $13.1 \pm 2.0^{c}$ \\
\hline Donepezil & - & $(2.31 \pm 0.48) 10^{-8}$ & $(7.42 \pm 0.39) 10^{-6}$ & $<5$ \\
\hline Galantamine & - & $(2.01 \pm 0.15) 10^{-6 \mathrm{~d}}$ & $(2.07 \pm 0.15) 10^{-5 \mathrm{~d}}$ & $<5^{\mathrm{d}}$ \\
\hline Rivastigmine & - & $(3.03 \pm 0.21) 10^{-6 \mathrm{~d}}$ & $(3.01 \pm 0.14) 10^{-7 d}$ & $17.8 \pm 1.6^{\mathrm{d}}$ \\
\hline
\end{tabular}

\footnotetext{
${ }^{\mathrm{a}}$ Human recombinant $\mathrm{AChE}$ and $\mathrm{BChE}$ from human serum were used. $\mathrm{IC}_{50}$ values represent the concentration of inhibitor required to decrease enzyme activity by $50 \%$ and are the mean of two independent measurements, each performed in duplicate; $\mathrm{IC}_{50}$ values were determined by Ellman's method; SEM $=$ standard error of the mean. ${ }^{\text {b } \%}$ inhibition of $50 \mu \mathrm{M} A \beta(1-42)$ self-aggregation by $10 \mu \mathrm{M}$ compound. The $A \beta(1-42) /$ inhibitor ratio was equal to $5 / 1$. Values are the mean of two independent experiments, each performed in duplicate; ${ }^{\mathrm{c}}$ from reference [15]; ${ }^{\mathrm{d}}$ from reference [32]; nd stands for not determined.
}

As reported in Table 1, AChE inhibition was strictly dependent on the chain length separating the pharmacophoric functions. The most effective compounds were $4\left(\mathrm{IC}_{50}=0.773 \mu \mathrm{M}\right)$ and, albeit to a lower extent, $3\left(\mathrm{IC}_{50}=2.39 \mu \mathrm{M}\right)$, having a six and five methylene spacer, respectively, between the carbazole unit and the benzyl-piperazine moiety. Notably, inhibition of ACh cleavage by 3 was in line with that of current anticholinesterase drugs galantamine and rivastigmine (Table 1), while 4 performed slightly better. Conversely, shortening (1 and 2) or lengthening (5) the flexible tether resulted in an evident drop in activity. This behavior is typically related to a dual binding mode of inhibition [33-36], where a suitable chain length is determinant to allow compounds contacting the two recognition sites which distinguish the peculiar topology of AChE, namely internal and peripheral anionic sites [37].

To verify this hypothesis and devise a structural explanation on how the length of the flexible linker modulates the AChE inhibitory potency of the synthesized compounds, docking simulations were performed 
at the human AChE (hAChE) gorge by means of ICM3.8 (Molsoft LLC, San Diego, CA-USA) for 4 and its homologues 3 and 5. Donepezil (Figure 3A) and the inhibitor of the peripheral anionic site (PAS) propidium were used for comparison (Figure 3B).

The model of the enzyme was based on the crystal structure of hAChE in complex with fasciculin (PDB code 1B41). The $\mathbf{4}$ hexyloxy spacer allows an optimal dual site interaction at both at the catalytic and at the PAS sites: a) the terminal benzyl group of the inhibitor establishes $\pi-\pi$ interactions with Trp86; b) the protonated nitrogen atom can form a $\pi$ - cation interaction with the side chain of Tyr337; and c) the carbazole group establishes $\pi-\pi$ interactions with Trp286. Interestingly, when the predicted bound conformation of 4 is compared to the known pose of donepezil (Figure 2A) it can be seen that it overlaps well (PBD code 1EVE). Moreover, the carbazole nitrogen of 4 perfectly overlaps with the phenantridinic nitrogen of the propidium bound conformation (Figure 2B). Derivatives with shorter (3) and longer (5) linkers cannot be efficiently fitted in the binding pocket (Figure S1 and Figure S2 in Supporting Information). Concerning the inhibition of human $\mathrm{BChE}(\mathrm{hBChE})$, the length of the spacer did not significantly influence the inhibitory profile, as all the compounds presented similar inhibitory values in the micromolar range (Table 1). Interestingly, this resulted in a balanced dual AChE/BChE inhibitory potency for $\mathbf{3}$ and $\mathbf{4}$.With better understanding of the inter-relationship of $\mathrm{AChE}$ and $\mathrm{BChE}$ in the $\mathrm{AD}$ brain, this balanced action may have potential therapeutic benefits, as both enzymes are recognized therapeutic targets at different stages of the pathology. Indeed, as $\mathrm{AD}$ evolves, the activity of $\mathrm{AChE}$ decreases while that of $\mathrm{BChE}$ increases [5], in an attempt to modulate $\mathrm{ACh}$ levels in cholinergic neurons. Therefore, the synergistic inhibition of both cholinesterase (ChE) enzymes might be a more valuable approach for the moderate form of the AD. 


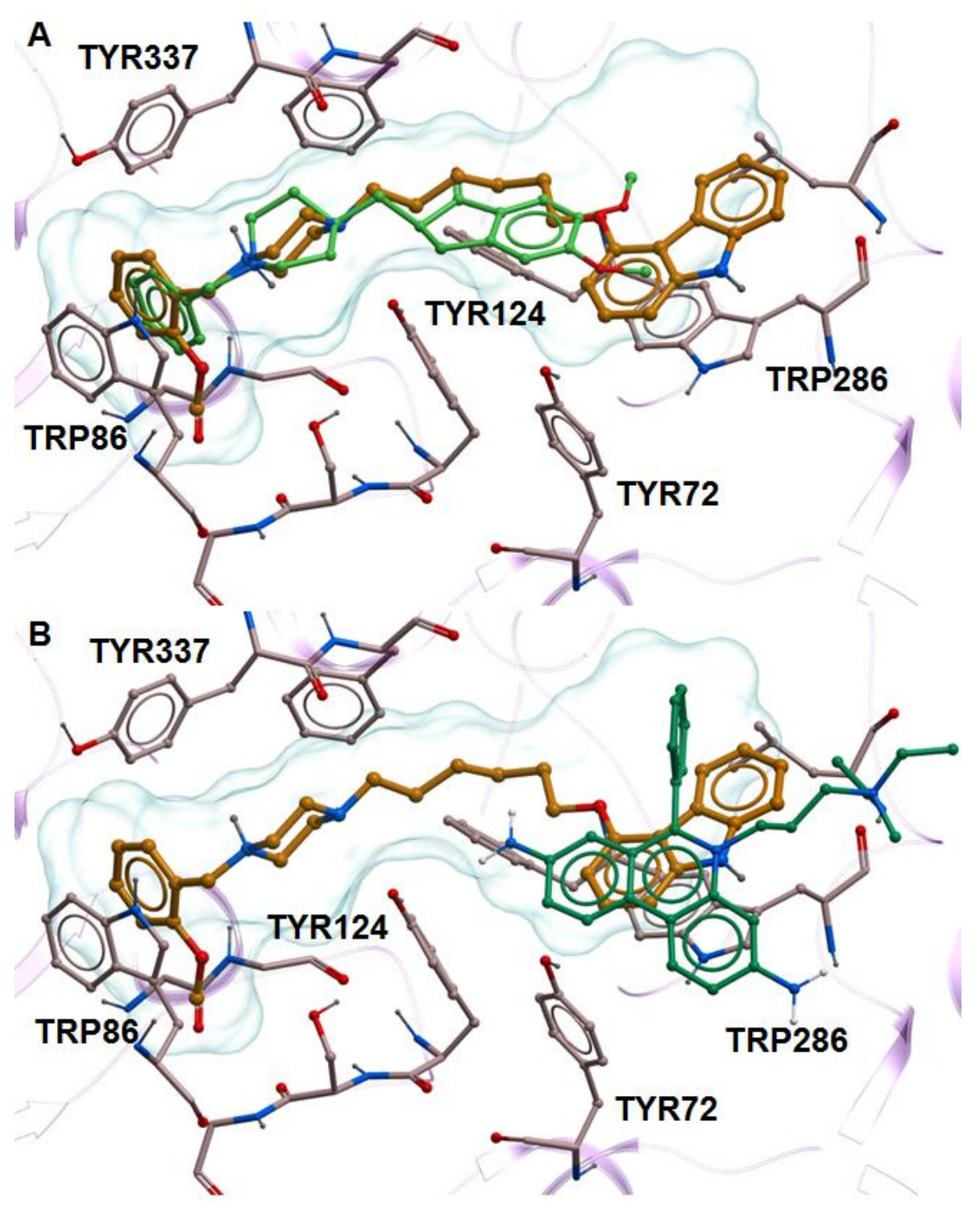

Figure 3. The bound conformation of 4 at the binding site of hAChE predicted by docking simulations. The ligand is reported in orange X-sticks. The key residues of the binding pocket are reported in light grey x-sticks and labelled explicitly. The rest of the protein is described by a transparent pink cartoon representation. A transparent white mesh describes the boundaries of the binding pocket. (A) The overlap between 4 and donepezil crystallographic pose (light green $x$-sticks, PDB CODE: 1EVE). (B) The overlap between 4 and propidium crystallographic pose (dark green X-sticks, PDB CODE: 1N5R)

As a part of our multitarget project, we sought to verify if anti-ChE activity of compounds $\mathbf{1 - 5}$ could be accompanied by effective nAChR activation, as we envisioned the weak perturbation of different AChmediated targets as a valuable strategy to gain potential additive or synergistic enhancement of cholinergic neurotransmission. 
Table 2 Binding affinity (Ki, nM) of compounds 1-5 to $\alpha_{4} \beta_{2}$ and $\alpha_{7}$ rat nicotinic receptor subtypes, labelled with [ $\left.{ }^{3} \mathrm{H}\right]-$ epibatidine and $\left[{ }^{125} \mathrm{I}\right]-\alpha$-bungarotoxin, respectively ${ }^{\mathrm{a}}$.

\begin{tabular}{|l|l|ll|}
\hline Compd & $\mathrm{N}$ & $\begin{array}{l}\mathrm{K}_{\mathrm{i}}, \mu \mathrm{M}(\% \mathrm{CV}) \\
\alpha_{4} \beta_{2}\end{array}$ & $\begin{array}{l}\mathrm{K}_{\mathrm{i}}, \mu \mathrm{M}(\% \mathrm{CV}) \\
\alpha_{7}\end{array}$ \\
\hline $\mathbf{1}$ & 3 & $22.70(22)$ & $29.20(50)$ \\
$\mathbf{2}$ & 4 & $44.00(18)$ & $15.20(62)$ \\
$\mathbf{3}$ & 5 & $66.80(21)$ & $35.30(72)$ \\
$\mathbf{5}$ & 6 & $90.00(19)$ & $120.00(69)$ \\
\hline
\end{tabular}

${ }^{a}$ The $K_{\mathrm{i}}$ values were derived from $\left[{ }^{3} \mathrm{H}\right]$-epibatidine and $\left[{ }^{125} \mathrm{I}\right]$ - $\alpha$-bungarotoxin saturation and three competition binding experiments on cortical and hippocampal rat brain membranes The curves were fitted using a nonlinear least squares analysis program and the $F$ test. The numbers in brackets represent the \% coefficient of variation $(\mathrm{CV})$.

Therefore, preliminary binding assays were carried out to assess whether compounds 1-5 could displace $\left[{ }^{3} \mathrm{H}\right]$-epibatidine and $\left[{ }^{125} \mathrm{I}\right]-\alpha$-bungarotoxin from $\alpha_{4} \beta_{2}$ and $\alpha_{7}$ receptor subtypes of rat cortex, respectively (Table 2). All of the compounds presented a micromolar affinity profile with $\mathrm{K}_{\mathrm{i}}$ values ranging from 15 to $120 \mu \mathrm{M}$, without discriminating the receptor subtypes. The binding affinity to $\mathrm{nAChRs}$ seemed to be influenced by the chain length separating the pharmacophoric functions, even though, unfortunately, an inverted trend of efficacy was observed compared to AChE inhibition, with compound 4 the less efficacious at both receptor subtypes. The Ki values determined by binding studies do not allow comparison between the nicotinic efficacies of 1-5 and galantamine, for which a sensitizing action on nAChRs by allosteric (and not ortosteric) modulation of the $\alpha_{4} \beta_{2}$ and $\alpha_{7}$ subtypes has been proposed to complement cholinesterase inhibition [38].

To substantiate the mode of action toward nAChRs, we also tested synthesised compounds on $\alpha_{4} \beta_{2}$ and $\alpha_{7}$ nAChRs subtypes, heterologously expressed in Xenopus oocytes by using two-electrode voltage clamp. Membrane potential was clamped at $-80 \mathrm{mV}$ and, to evaluate the activity of compounds $\mathbf{1 - 5}$, they were applied at two different concentrations $(10$ and $100 \mu \mathrm{M})$ in comparison with the agonist $\mathrm{ACh}$. 


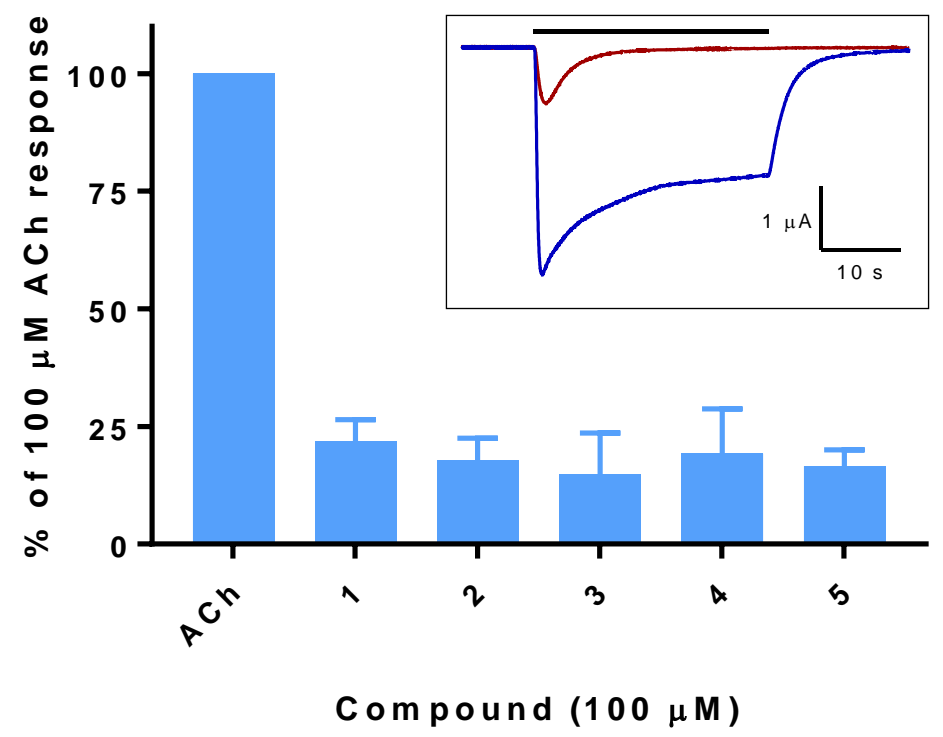

Figure 4. Responses of $\alpha_{4} \beta_{2}$ to 1-5 $(100 \mu \mathrm{M}) .1-5$ at a concentration of $100 \mu \mathrm{M}$ were applied to Xenopus oocytes clamped at $-80 \mathrm{mV}$ and their responses normalised to that of $100 \mu \mathrm{M}$ ACh in the same cell $(\mathrm{n}=5-8)$. Inset: Current responses to $100 \mu \mathrm{M}$ ACh (blue) and $100 \mu \mathrm{M} 5$ (red) on the same oocyte expressing $\alpha_{4} \beta_{2}$. The black bar indicates application of the agonist.

While a negligible effect was detected at $10 \mu \mathrm{M}$ concentration (see Table S1 in Supporting Information), a weak activation on membrane current for the $\alpha_{4} \beta_{2}$ receptor subtype was observed at $100 \mu \mathrm{M}$ for all compounds, ranging from 15 to $22 \%$ of the response to $100 \mu \mathrm{M}$ ACh (Figure 4). Conversely, no responses could be detected on $\alpha_{7} \mathrm{nAChR}$, probably because this receptor subtype has a lower sensitivity to ACh [39] or because of the fast desensitization which could considerably complicate the ion current measurements. Low levels of persistent activation of $\alpha_{4} \beta_{2}$ receptors may be beneficial in terms of improving the excitability of postsynaptic neurons or enhancing neurotransmitter release presynaptically.

Finally, to disclose the proposed dual interventions on cholinergic and amyloidogenic pathways, the ability of compounds 1-5 towards the inhibition of $A \beta(1-42)$ self-aggregation was investigated. The carbazole building block (6) was also included in the study to clarify the role of this fragment. A ThT-based fluorimetric assay was used to quantify $\mathrm{A} \beta$ fibril formation in the presence and absence of inhibitor (A $\beta /$ inhibitor ratio 5/1). Data in Table 1 show that all compounds at $10 \mu \mathrm{M}$ concentration inhibited $\mathrm{A} \beta(1-42)$ self-aggregation, with inhibition by $\mathbf{2 - 5}$ ranging from 28 to $36 \%$, similarly to the known anti-aggregating 
compound curcumin $(34.4 \pm 1.1 \%$, at $10 \mu \mathrm{M})[40]$. The observed efficacies are significantly higher with respect to the carbazole moiety alone, corroborating the importance of substitution for boosting the inhibitory capability towards $A \beta$ assembly.

Interestingly, any of the marketed AChEIs, including galantamine, display significant high antiaggregating ability (Table 1). Consequently, these new compounds propose an expanded multitarget profile for AChEIs, through the incorporation of additional and mutual interconnected anti-AD properties.

\section{Conclusion}

The multifactorial nature of $\mathrm{AD}$ is a critical issue which hampers the discovery of effective disease modifying therapies. In this light, multitarget compounds have recently been proposed to address simultaneously multiple targets critically involved in the AD network [41]. By exploiting this approach, the present study provided compounds $\mathbf{3}$ and $\mathbf{4}$ which presented a moderate-affinity profile against all the selected targets. Particularly, a low but significant activation of $\alpha_{4} \beta_{2}$ nAChRs (15-20\% at $\left.100 \mu \mathrm{M}\right)$ was combined to a micromolar AChE inhibitory profile. This latter activity is not dissimilar to that of some of the current marketed drugs. What's more, the ability to reduce $A \beta$ self-aggregation shown by $\mathbf{3}$ and $\mathbf{4}$ at $10 \mu \mathrm{M}$ makes them very interesting starting points for further development. In fact, when two or more targets are interconnected, as for cholinergic neurotransmission (AChE, nAChRs) and amyloid, a weak perturbation of one or both partner systems might be sufficient to accomplish a significant modification of the whole scenario, in a synergistic way. Furthermore, the mild but multiple perturbation might prevent unwanted compensatory mechanisms that are typical of high-affinity single target compounds [42].

\section{Future perspectives}

Despite the opportunities conceptually offered by the multitarget drug-design strategy and the enthusiasm generated around it, the effective development of multitarget drugs is extremely challenging. Indeed, the generation of a valuable multitarget drug is a compromise and balance iterative process.

From the start, selection of the targets is fundamental to establish whether their modulation could lead to additive effects or synergistic potentiation [43]. Herein, we envisaged the simultaneous modulation of human 
$\mathrm{ChE}$ and nAChRs as a suitable tool to synergistically turn up the cholinergic transmission, which is impaired in AD. More interestingly, based on the widely recognized cross-talk between $\mathrm{nAChRs}$ and the $\mathrm{A} \beta$ pathway, we proposed nAChR activation as a crucial tether between the symptomatic relief of cholinergic potentiation and the neuroprotective prospects of antiaggregating agents. Thus, by intervening on the three pathways, we aim to synergistically interfere with crucial points of recognized AD pathogenic players. Aware of the work still to be done in terms of potency, affinity-balancing and developing $\alpha_{7}$ agonism, we believe that these new compounds may represent a starting point for a further optimization process. We are also confident that our rationale may offer a valuable input towards translating the findings of network medicine into clinically actionable tools.

\section{Executive summary}

- $\mathrm{AD}$ has a multifactorial nature, with a network of simultaneous and synergistic processes.

- The rational design of single chemical entities addressing multiple targets is a promising and challenging strategy, with higher beneficial impact to confront AD.

- Selection of the targets is crucial to achieve additive effects or synergistic potentiation.

- The amyloidogenic and cholinergic pathways, while being considered independent for years, share a number of molecular features that merge at several points.

- The present study provides new molecules able to potentiate the cholinergic neurotransmission, by combining direct nicotinic receptor activation to acetylcholinesterase inhibition, and to inhibit $\mathrm{A} \beta$ aggregation.

- The obtained results offer a valuable input for a further optimization process. 


\section{Graphical Abstract}

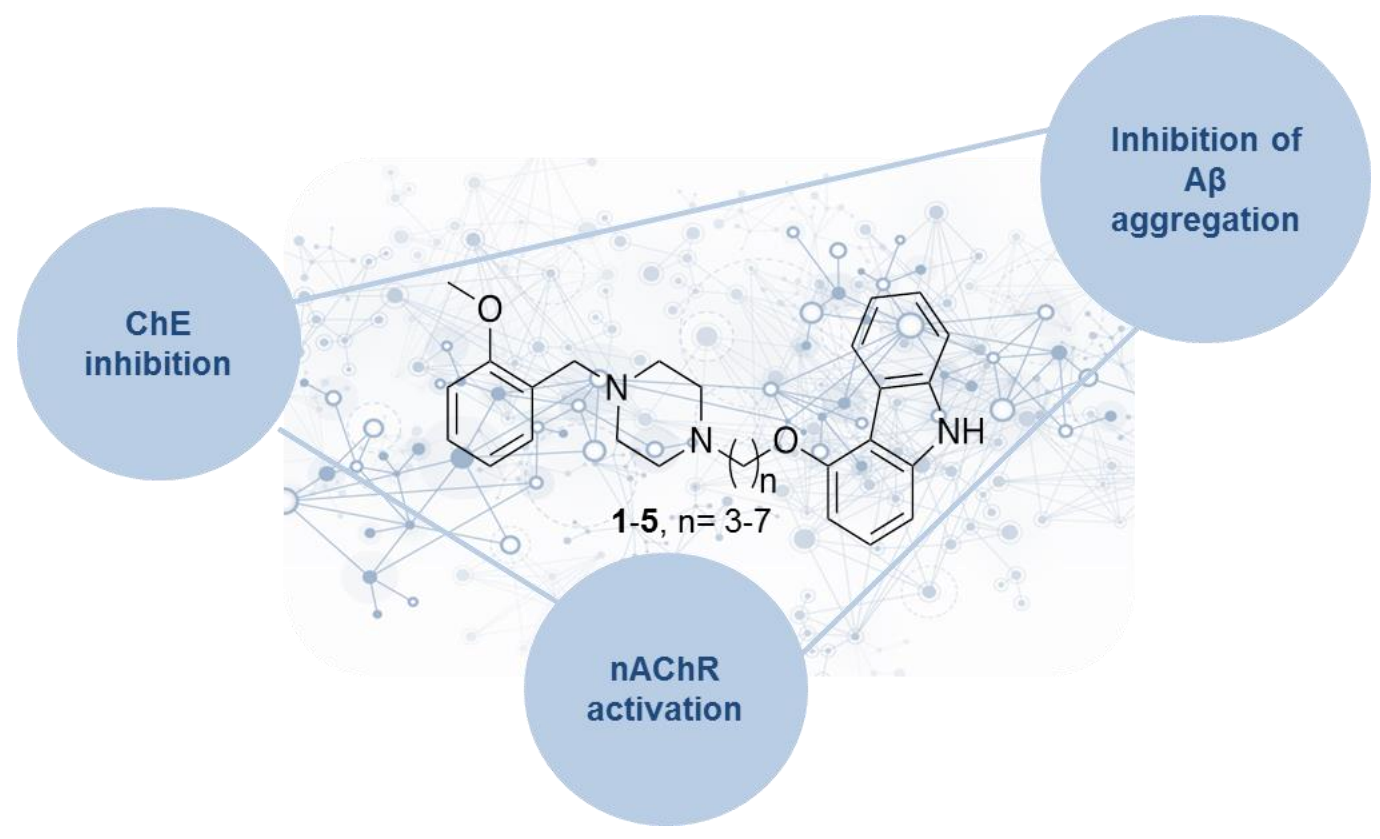




\section{References}

Papers of special note have been highlighted as: * of interest; ** of considerable interest.

1. Graham WV, Bonito-Oliva A, Sakmar TP. Update on Alzheimer's Disease Therapy and Prevention Strategies. Annu.Rev. Med. 68, 413-430 (2017).

* Comprehensive and timely analysis of Alzheimer's disease therapy and prevention strategies.

2. Talwar P, Sinha J, Grover S et al. Dissecting Complex and Multifactorial Nature of Alzheimer's Disease Pathogenesis: a Clinical, Genomic, and Systems Biology Perspective. Mol. Neurobiol. 53(7), 4833-4864 (2016).

3. Govoni S, Mura E, Preda S et al. Dangerous liaisons between beta-amyloid and cholinergic neurotransmission. Curr. Pharm. Des. 20(15), 2525-2538 (2014).

** Outstanding review on the multifaceted interconnections between cholinergic transmission and betaAmyloid.

4. Greig NH, Utsuki T, Yu Q et al. A new therapeutic target in Alzheimer's disease treatment: attention to butyrylcholinesterase. Curr. Med. Res. Opin. 17(3), 159-165 (2001).

5. Mushtaq G, Greig NH, Khan JA, Kamal MA. Status of acetylcholinesterase and butyrylcholinesterase in Alzheimer's disease and type 2 diabetes mellitus. CNS Neurol. Disord. Drug Targets 13(8), 1432-1439 (2014).

6. Vanpatten S, Al-Abed Y. The challenges of modulating the 'rest and digest' system: acetylcholine receptors as drug targets. Drug Discov. Today 22(1), 97-104 (2017).

7. Lombardo S, Maskos U. Role of the nicotinic acetylcholine receptor in Alzheimer's disease pathology and treatment. Neuropharmacology 96(Pt B), 255-262 (2015).

8. Terry AV, Callahan PM, Hernandez CM. Nicotinic ligands as multifunctional agents for the treatment of neuropsychiatric disorders. Biochem. Pharmacol. 97(4), 388-398 (2015).

9. Buckingham SD, Jones AK, Brown LA, Sattelle DB. Nicotinic acetylcholine receptor signalling: roles in Alzheimer's disease and amyloid neuroprotection. Pharmacol. Rev. 61(1), 39-61 (2009).

10. Puzzo D, Gulisano W, Arancio O, Palmeri A. The keystone of Alzheimer pathogenesis might be sought in A $\beta$ physiology. Neuroscience 307, 26-36 (2015). 
* Valuable paper on the role of beta-amyloid between pathology and physiology.

11. Bolognesi ML. Polypharmacology in a single drug: multitarget drugs. Curr. Med. Chem. 20(13), 1639-1645 (2013).

* Critical review on the multitarget drug discovery approach from a medicinal chemistry perspective.

12. Rosini M, Simoni E, Caporaso R, Minarini A. Multitarget strategies in Alzheimer's disease: benefits and challenges on the road to therapeutics. Future Med. Chem. 8(6), 697-711 (2016).

13. Pérez DI, Martínez A, Gil C, Campillo NE. From Bitopic Inhibitors to Multitarget Drugs for the Future Treatment of Alzheimer's Disease. Curr. Med. Chem. 22(33), 3789-3806 (2015).

14. Howlett DR, George AR, Owen DE, Ward RV, Markwell RE. Common structural features determine the effectiveness of carvedilol, daunomycin and rolitetracycline as inhibitors of Alzheimer beta-amyloid fibril formation. Biochem. J. 343(Pt 2), 419-423 (1999).

15. Rosini M, Simoni E, Bartolini M et al. Inhibition of acetylcholinesterase, beta-amyloid aggregation, and NMDA receptors in Alzheimer's disease: a promising direction for the multi-target-directed ligands gold rush. J. Med. Chem. 51(15), 4381-4384 (2008).

16. Cavalli A, Bolognesi ML, Capsoni S et al. A small molecule targeting the multifactorial nature of Alzheimer's disease. Angew. Chem. Int. Ed. Engl. 46(20), 3689-3692 (2007).

17. Rosini M, Simoni E, Bartolini M et al. Exploiting the lipoic acid structure in the search for novel multitarget ligands against Alzheimer's disease. Eur. J. Med. Chem. 46(11), 5435-5442 (2011).

18. Haydar SN, Ghiron C, Bettinetti L et al. SAR and biological evaluation of SEN12333/WAY317538: Novel alpha 7 nicotinic acetylcholine receptor agonist. Bioorg. Med. Chem. 17(14), 52475258 (2009).

* Significant work describing the SAR and biological evaluation of the alpha 7 nicotinic acetylcholine receptor agonist $S E N 12333 / W A Y-317538$.

19. Ellman GL, Courtney KD, Andres V, Feather-Stone RM. A new and rapid colorimetric determination of acetylcholinesterase activity. Biochem. Pharmacol. 7, 88-95 (1961).

20. Bartolini M, Bertucci C, Bolognesi ML, Cavalli A, Melchiorre C, Andrisano V. Insight into the kinetic of amyloid beta (1-42) peptide self-aggregation: elucidation of inhibitors' mechanism of action. ChemBioChem 8(17), 2152-2161 (2007). 
21. Naiki H, Higuchi K, Nakakuki K, Takeda T. Kinetic analysis of amyloid fibril polymerization in vitro. Lab. Invest. 65(1), 104-110 (1991).

22. Levine H. Thioflavine T interaction with synthetic Alzheimer's disease beta-amyloid peptides: detection of amyloid aggregation in solution. Protein Sci. 2(3), 404-410 (1993).

23. Sala M, Braida D, Pucci L et al. CC4, a dimer of cytisine, is a selective partial agonist at $\alpha 4 \beta 2 / \alpha 6 \beta 2$ nAChR with improved selectivity for tobacco smoking cessation. Br. J. Pharmacol. 168(4), 835-849 (2013).

24. Kryger G, Harel M, Giles K et al. Structures of recombinant native and E202Q mutant human acetylcholinesterase complexed with the snake-venom toxin fasciculin-II. Acta Crystallogr. D. Biol. Crystallogr. 56(Pt 11), 1385-1394 (2000).

25. Belluti F, Bartolini M, Bottegoni G et al. Benzophenone-based derivatives: a novel series of potent and selective dual inhibitors of acetylcholinesterase and acetylcholinesterase-induced beta-amyloid aggregation. Eur. J. Med. Chem. 46(5), 1682-1693 (2011).

26. Halgren TA. Merck molecular force field. J. Comput. Chem. 17, 490-641 (1996).

27. Bourne Y, Taylor P, Radić Z, Marchot P. Structural insights into ligand interactions at the acetylcholinesterase peripheral anionic site. EMBO J. 22(1), 1-12 (2003).

28. Kryger G, Silman I, Sussman JL. Structure of acetylcholinesterase complexed with E2020 (Aricept): implications for the design of new anti-Alzheimer drugs. Structure 7(3), 297-307 (1999).

29. Totrov M, Abagyan R. Flexible protein-ligand docking by global energy optimization in internal coordinates. Proteins Suppl. 1, 215-220 (1997).

30. Nemethy G, Gibson KD, Palmer KA et al. Energy parameters in polypeptides. 10. Improved geometrical parameters and nonbonded interactions for use in the ECEPP/3 algorithm, with application to proline-containing peptides. J. Phys. Chem. 96, 6472-6484 (1992).

31. Totrov M, Abagyan R. In derivation of sensitive discrimination potential for virtual screening. RECOMB '99. Presented at: The Third Annual International Conference on Computational Molecular Biology, Lyon, France, 1999. 
32. Bolognesi ML, Cavalli A, Valgimigli L et al. Multi-target-directed drug design strategy: from a dual binding site acetylcholinesterase inhibitor to a trifunctional compound against Alzheimer's disease. $J$. Med. Chem. 50(26), 6446-6449 (2007).

33. Simoni E, Daniele S, Bottegoni G et al. Combining galantamine and memantine in multitargeted, new chemical entities potentially useful in Alzheimer's disease. J. Med. Chem. 55(22), 9708-9721 (2012).

34. Rosini M, Simoni E, Bartolini M et al. The bivalent ligand approach as a tool for improving the in vitro anti-Alzheimer multitarget profile of dimebon. ChemMedChem 8(8), 1276-1281 (2013).

35. Benchekroun M, Bartolini M, Egea $\mathrm{J}$ et al. Novel tacrine-grafted Ugi adducts as multipotent antiAlzheimer drugs: a synthetic renewal in tacrine-ferulic acid hybrids. ChemMedChem 10(3), 523-539 (2015).

36. Mantoani SP, Chierrito TP, Vilela AF, Cardoso CL, Martínez A, Carvalho I. Novel TriazoleQuinoline Derivatives as Selective Dual Binding Site Acetylcholinesterase Inhibitors. Molecules 21(2), (2016).

37. Pang YP, Quiram P, Jelacic T, Hong F, Brimijoin S. Highly potent, selective, and low cost bistetrahydroaminacrine inhibitors of acetylcholinesterase. Steps toward novel drugs for treating Alzheimer's disease. J. Biol. Chem. 271(39), 23646-23649 (1996).

38. Samochocki M, Höffle A, Fehrenbacher A et al. Galantamine is an allosterically potentiating ligand of neuronal nicotinic but not of muscarinic acetylcholine receptors. J. Pharmacol. Exp. Ther. 305(3), 1024-1036 (2003).

39. Kachel HS, Patel RN, Franzyk H, Mellor IR. Block of nicotinic acetylcholine receptors by philanthotoxins is strongly dependent on their subunit composition. Sci Rep. 6, 38116 (2016).

40. Bolognesi ML, Bartolini M, Tarozzi A et al. Multitargeted drugs discovery: balancing anti-amyloid and anticholinesterase capacity in a single chemical entity. Bioorg. Med. Chem. Lett. 21(9), 2655$2658(2011)$.

41. Guzior N, Wieckowska A, Panek D, Malawska B. Recent development of multifunctional agents as potential drug candidates for the treatment of Alzheimer's disease. Curr. Med. Chem. 22(3), 373-404 (2015). 
42. Rosini M. Polypharmacology: the rise of multitarget drugs over combination therapies. Future Med. Chem. 6(5), 485-487 (2014).

43. Bottegoni G, Favia AD, Recanatini M, Cavalli A. The role of fragment-based and computational methods in polypharmacology. Drug Discov. Today 17(1-2), 23-34 (2012). 